\title{
Brand Valuation of Commercial Banks in Bangladesh: An
}

\section{Application of Marketing Profitability}

\author{
Mahamudul Hasan ${ }^{1 *}$, Kazi Tareq Ullah ${ }^{1} \&$ Dr. Haripada Bhattacharjee ${ }^{2}$ \\ ${ }^{1}$ Department of Business Administration, School of Business, Uttara University, Dhaka, Bangladesh \\ ${ }^{2}$ Department of Marketing, Faculty of Marketing, University of Dhaka, Dhaka, Bangladesh \\ *Mahamudul Hasan, Email: mahamudulmkt@gmail.com
}

\begin{abstract}
The competitive race of banking sector in the world economy is rapidly enforcing the importance of brand valuation. The acceptance of brand valuation has been questionable in several times due to the subjective measurement that derives from customers' volatile perceptions. At the same time, financially focused model provides only an assessment of the economic value of brand. It is still a challenging task to compute the brand valuation depending only on financial data. Interbrand technique (2004) is one of the best approaches of calculating brand value within the community of marketing. Our valuation approach followed the A.C. Nielsen valuation model (2006) for valuing brand which is multiple of “Annual sales of representative brand", "Net operating margin”, "Relative brand strength”, and “Perpetual annuity NPV discount factor". This paper explores the Brand Valuation (BV) and identifies the relative position of banks based on measuring marketing contribution. Data have been collected from first generation private commercial bank's annual reports and analyzed by using perpetual NPV continuous discount factor. The objective measure of $B V$ for commercial banks was developed using Net Marketing Contribution (NMC), Relative Brand Strength (RBS) and Perpetual Net Present Value Continuous Discount Factor (PNPVCDF). The measures of brand valuation will ease the understanding regarding marketing profitability, brand performance and relative position in the competitive field.
\end{abstract}

\section{Keywords}

commercial banks, interest income, net interest income, marketing return on investment, net marketing contribution, relative brand strength

\section{Introduction}

The performance from marketing activities in the form of finance has been considered to measure the brand value with increasing pressure of accountability since 1980s. Many researchers have already conducted to quantify the brand value for the product of manufacturing organization, whereas much research has yet to conduct about the valuation for financial services organization like banks. Since the valuation of brand is as easy to quantify for products as not easy to quantify for services. In 1984 the 
newspaper owned by "Rupert Murdoch" has determined the brand value of its own on the Australian News Group balance sheet and Interbrand (1988) has quantified the brands for the defence of bid in the UK's Rank Hovis McDougall (Salinas et al., 2009). Since then, brand valuation methods have widely been used especially for the measurement of marketing performance, branding research and the demand of differentiating firms' services through their valuation.

Widespread interest in valuation of brand arises when the brands, or the companies owning the brands, are sold and bought (Salinas et al., 2009). As part of it, this study has found that Philip Morris paid $\$ 12.9$ billion for Kraft in 1989, which was six times its net asset value (Tekan et al., 2012). In calculation of brand valuation, the use of economic value may endow with the multidimensionality as a financial measure of brand equity. In response to that multiple reasons have been developed to facilitate the quantification of brand value (Aaker \& Alvarez del Blanco, 1994). First reason brand has to be valued with transparency. Second reason includes investment; any investment made to enhance brand value has to be justified. Third includes product development, quantification of brand value is a core element in the products development. Final reason includes trademark, some authors expresses that it is an opportunity to the valuation of trademark, it establishes positive link between the commercial subsystem of the firm and the financial subsystem (Blackett, 1989). The interest of executive Managers $\&$ Researchers of knowledge management have been increasing for making the quantification of brand value (Tekan et al., 2012).

Strategic consideration is another important focus for measuring the brand value in today. This valuation can serve to strategic brand management by internal analyses which will enable to increase of economic value of brands. Increasing productivity, understanding consumer behavior and brand attitude are very important for marketing managers. In the literature it has been stated that efficient brand management begins with an excellent measure of its value (Aaker \& Alvarez del Blanco, 1995b; Crimmins, 1992).

Marketing is largely distinct here as what the company does to accomplish customer preference and, side by side achieve its own goals (Webster, 1992). In view of that every bank has some interest in assessing marketing performance. Before the study of measuring the brand value for commercial banks, "Marketing profitability metrics of commercial banks" has been measured (Hasan, 2012). The previous study of "Marketing profitability metrics" has found that "Net profit" and "Operating profit" are good indicators to realize the banks' performance but sometimes this financial profitability may not show the clear picture of banks' brand performance. Next this study developed the formula for measuring the brand value using Marketing Profitability (MP) with an approach of Net Present Value (NPV) discounting factor for commercial banks in Bangladesh as a new idea of this valuation.

The scenario even in USA appeared to have a lot of confusion and uncertainty (Seetharaman et al., 2001). Therefore, we would like to keep up our strength on "Brand valuation" of commercial banks by capitalizing A.C. Nielsen brand valuation approach (2006) of "Composite business finance or behavioral model". Since brand value can be helpful as a blueprint of a bank for investors, customers 
and third party banks. This valuation can make some clear understanding about marketing contributions and returns. The advantages of brand value determination will make sure that marketing resources are appropriately distributed to where it will carry the superior value to the organization. The measures of brand valuation will also simplify the decisions regarding marketing expenses value, the brand manager's performance evaluation, and a strong brand building decision making. Furthermore, brand valuation ensures that brand-licensing fees that correctly reflect the benefits received (Keller, 1998).

\section{Literature Review}

Brand valuation plays a key important role in today with regard to marketing, accounting, management, mergers and acquisitions. In the late 1980s financial approaches of brand value ultimately helps to make some understanding and assessing the value of brands. Regarding a global valuation method, Drefeldt (2006) states that the important thing is the transparency; that the companies show how the valuation was made. Members of the IASB (2006) think that an international valuation method would be a good idea to increase the comparability of Brand Assets. This view is also partly supported by Grojer (2006) who believes that some idea of which costs that an activated brand should consist of, is necessary. For many days, Marketing Accounting Standard Board (MASB) has been trying to create awareness regarding financial reporting of marketing intangibles. However, there are many debates towards the acceptance of method of intangible assets. Valuation through historic costs based on the expenses is necessary to build or form a brand. Lack of brand earning potential is the core problem of this model.

Cost approach, market approach, income approach and other combined approach are initial segments in the discussion of the development of brand valuation methods. According to the cost approach, brand value is estimated by historical cost of creation (Haigh, 2000; Hirose, 2002; Anson, 2005) and the brand is also valued by the cost of recreating the brand today using current prices (Smith, 1997; Haigh, 2000; Boos, 2003; Anson, 2005). Based on market approach, brand is valued by recent transactions of similar brands in the similar markets (Smith, 1997; Ambler \& Barwise, 1998; Haigh, 2000; Anson, 2005).

"Comparison in price, in sales and in profitability", "Strength analysis by demand", "Excess value", "Brand value versus asset value", "Customer Life time Value (CLV)", and "Royalty relief" have been considered as income approach. This study divides the comparison technique in two different ways. One is "Price and sales comparison" and other one is "Financial profitability comparison". Differential unit price of the brand in comparison with a generic product is the valuation technique known as "Price premium" (Ambler \& Barwise, 1998; Tollington, 1999; Smith \& Parr, 2000; Zimmermann, 2001; Boos, 2003; Salinas, 2007). This technique includes two important points. One is "Conjoint analyses" and other one is "Hedonic analyses". "Differential of price to sales ratio" is other technique of price and sales comparison approach. This technique calculates brand value by the analysis of "Price to sales ratio" of branded company compared to "Price to sales ratio" of unbranded 
company (Damodaran, 1996; Fernandez, 2001). According to the comparison of financial profitability, this study has found two different methods of brand valuation. One is "Gross margin comparison" (Smith, 1997) and other one is "Operating profit comparison" (Smith, 1997; Smith \& Parr, 2000). Brand strength is leaded by the demand and function of brand equity which influences the brand in the decision making process (Brand Finance, 2000; Zimmermann et al., 2001; BrandEconomics, 2002; Sattler et al., 2002; Brandient, 2004; Brand Metrics, 2004; Interbrand Zintzmeyer \& Lux, 2004; Kumar \& Hansted Blomqvistm, 2004; Mussler et al., 2004; A.C. Nielsen, 2006; Salinas, 2007).

In the point of excess value, this study found three different researches such as "Excess cash flow", "Excess margin" and "Marginal cash". Excess cash flow is derived from the attribution of free cash flow to the brand by deducting the return of other assets different from brand from the free cash flow of the firm (Fernández, 2001; Kam \& Angberg, 2003). Next excess margin which calculates the brand value by the portion of additional margin that is attributable to the brand (Smith, 1997; Pratt, 2002; Andriessen, 2004). Last one is marginal cash flows which are generated by the exploration of the brand are the base of brand valuation (Lamb, 2002; Smith, 1997; Anson, 2005) estimates the brand value by the sum of the core brand value and earnings from its products and brands. Based on CLV, brand is also valued (Fischer, 2007). "Royalty relief" (Barwise et al., 1989; Aaker, 1991; Smith, 1997; Ambler \& Barwise, 1998; Fernandez, 2001; Intangible business, 2001; Whitwell, 2003; Zimmermann et al., 2001; Boos, 2003; BBDO, 2004; Anson, 2005; Salinas, 2007) is frequently used as a technique of brand valuation. This technique calculates brand value by the estimation of future sales and then applying an appropriate royalty rate which is discounted back to a net present value.

Other combined methods include "Brand earnings", "Expansion and extension programs of brand", "Share value", "CAPM model", "Development cost and average annual revenues", "Brand power/Equity index", "Brand capability value model", "The model of composite financial and behavioral perspectives", "The A.C. Nielsen valuation model”, "Herp's approach model”, "Russell Abratt and Geoffrey Bick model". At first, "Brand earnings" calculates the brand value by the product of "Prestige Driver (PD)", "Expansion Driver (ED)", and "Loyalty Driver (LD)" (Hirose, 2002; Beccacece et al., 2006; Salinas, 2007). Next brand value is calculated as the product of "Intangible earnings", "Brand contribution" and "Brand multiple" (Millward, 2006; Salinas, 2007). On the basis of geographical expansion and brand extension, valuation for brand is developed by Fernandez (2001), Upton (2001), Ward and Ryals (2001), Lamb (2002). Stock price movement (Simon \& Sullivan, 1993; Motameni \& Shahrokhi, 1998) and differential share value due to the image (Damodaran, 1996; Fernandez, 2001) also contributes to the estimation of brand value. CAPM model is actually used to estimate a discount rate for brand valuation. This model capitalizes the cost of capital, incremental firm value and reputation index (Srivastava et al., 1997; Salinas, 2007). Zimmermann et al. (2001) estimates brand value from the cost of creation and development plus the $10 \%$ of the average annual revenues of the last 5 years. Based on surveys to executives, "Brand power" is estimated for the valuation of brand through a statistical model (Callaman, 2002; Corebrand, 2004; Salinas, 2007). 
Brand Capability Value (BCV) model is concern about how projected cash flow attributable to the brand (Rendon \& Morales, 2013). This model is mainly associated with the Interbrand Model. The link of economic and psychographical indicators was established in "The model of composite financial and behavioral perspective" by the study of Interbrand consultancy (2004) and Bekmeier-Feuerhahn, S. (1998). This model is also called "The integrated model of brand valuation" (Virvilaite \& Jucaityte, 2008). It comprises "The brand value in points" which will be produced by the calculation of "Brand strength factors", "Financial brand value factors" and "Financial brand strength factors". Brand strength factors (Brand loyalty, Brand awareness, Perceived quality, Brand associations and Brand asset) based on customer perception which may or may not be reliable.

The A.C. Nielsen valuation model (2006) has the calculation of brand value which is multiple of "Annual sales of representative brand", "Net operating margin", "Relative brand strength" and "Perpetual annuity NPV discount factor". Herp's approach model (1982) provides the effects of revenue and price, which are attributable entirely to brands. The results are expressed as a consumer specific utility of a brand regardless to the product's price. The brand value is obtained when this is multiplied by the total quantity of the product sold (Heider \& Strehlau, 2000). Abratt and Bick (2000) model introduced the brand equity calculation based on some differences among "Return on investment", "Return on assets" and "Economic value addition". One has to make sure that all the amounts are treated and classified in a similar manner in order to ensure that the comparison is meaningful. Algebraically this is determined as brand value is the product of "Difference in return on assets", "Asset base" and "Multiplier". Abratt and Bick (2000) also commenced the Brand valuation depending on future earnings. In this model the earnings arise from the brand are determined by value attempts. Abratt and Bick would try to forecast the profit from bank and discount it back at an appropriate rate (Reilly \& Schweihs, 1999). Algebraically this is determined as brand value is the summation of discounted brand profit. Calderón et al. (1997) defines brand value as: "the value of the additional cash flows generated by a product because it is identified with its brand". Abratt and Bick (2000) mentioned the brand valuation on discounted cash flow in their paper. Algebraically this is determined as brand value comes from the summation of discounted cash flows which is attributable to the brand.

Gunther and Kreigbaum-Kling surveyed (2001) among 79 German companies; $40 \%$ of their respondents said lack of an appropriate method is the main reason for not valuing brands. Financial brand value factors are determined by the difference of "Capitalization of company" and "Asset of company". Capitalization of company is calculated by the multiplication of "Market price of each stock and number of stock". Artificial tempering in market price is a problem of valuing indicators. In which way the indicators of Bangladeshi stock markets were falling down in 1996 and 2010. Therefore, this study could not rely on the market price of the companies" stock. Last one financial strength factors which refers to market-oriented brand valuation model by which financial strength of brand value factors is determined by the comparing market price and accountant price.

Published by SCHOLINK INC. 
The summary of different brand valuation approaches from above discussion is likely to focus on product based brand valuation for manufacturing organization not likely to focus on services like banking organization. The main reason we believe that BV calculation is not as easy to quantify for services as easy to quantify for products. As a result, the study will suffer to get the branded revenue from services organization like banks due to counting problems in services. Prior research of the brand or marketing of commercial banks in Bangladesh like Brand equity and resonance of banking services with the perspective of Bangladeshi Consumers (Farhana \& Islam 2012), Marketing on bank services of some selected private commercial banks in Dhaka City (Zahid, 2008), An exploratory study of Intellectual capital performance of the commercial banks in Bangladesh (Mohiuddin et al., 2006) are more concerned about the subjective measure of marketing performance. Therefore, we have tried in this study to make an objective measure of brand valuation based on the contribution of marketing profitability by published data of first generation commercial banks in Bangladesh.

\section{Objective}

The objective of this paper is twofold. Firstly, this paper develops to summarize our work in finding a useful measure of brand value for the commercial banks in Bangladesh by the usage of term "Brand Valuation (BV)" including; Interest Income (II), Net Marketing Contribution (NMC), Brand Strength (BS) using Marketing Return On Investment (MROI), Continuously Discounted Interest Income (CDII), Continuously Discounted Net Marketing Contribution (CDNMC), Continuously Discounted Marketing Return On Investment (CDMROI), Continuously Discounted Marketing Expenses (CDME) and Perpetual Net Present Value Continuous Discount Factor (PANPVCDF). Another objective of this paper is to identify the position of different commercial banks based on valuation.

\section{Methodology}

This study considers annual audited reports (2009 to 2013) of all first generation commercial banks in Bangladesh with the exception of the ICB Islamic bank limited, which has been inconsistent with regard to profitability during the last five years. Convenience sampling was used as the method of sampling by first generation banks. This study includes systematic and comparative secondary data analysis and quantitative studies. An exploratory research approach was applied for valuing brand by using a moderately converted model of brand valuation in the field of banking industry in Bangladesh. The information was gathered from the annual report of banks, literature books and journals. The contained data of financial statement have been reviewed and audited by the accountancy and accuracy. Maximum data gathering process today is leaded by trends of specific brands and markets, but not in measuring marketing inputs and output (Stewart, 2008). For this reason, raw data are not much of use for marketing planning and outcome measurement. In the financial sector often data reliability and validity are assumed. Some standards of this paper include: (1) Full data set that has been collected from annual reports of banks; (2) First generation banks have been classified as those Banks that are 
incorporated from the period of 1971-1990; (3) Subsidiaries of banks are not considered in this study; (4) Interest income is considered as "Sales revenue" of bank in the sense of marketing; (5) "Advertising and Publicity" is considered only as marketing related investment for the bank; (6) Brand value has been assessed for the end of year 2013; (7) The determination of brand value is subject to the number of banks and period of time.

\section{Measurement Tools for Assessing Brand Valuation}

\subsection{Net Marketing Contribution (NMC)}

Revell (1980) utilized the interest margin as a performance measure for U.S. commercial banks and defined the interest margin as the difference between interest income and expense divided by total assets. Marketing profitability is based on the investment in marketing and sales required to achieve certain levels of sales and gross margins (Best, R. J, 2010). Apple's net marketing contribution had a high correlation (.94) with operating income from 1999 to 2009. Apple's net profit was also influenced by its net marketing contribution. Net marketing contribution is a financial measure of marketing profitability and is computed as Net Marketing Contribution=Sales revenues $x$ Percent gross margin-Marketing \& Sales expenses.

Apple's net marketing contribution in 2009 was $\$ 10$ billion, as $\$ 36.54$ billion (Sales revenue) is multiplied by $36 \%$ (Percent gross margin) and less $\$ 3.12$ (Marketing \& sales expenses).

Net Marketing Contribution in products is calculated by "NMC=Net sales-Cost of goods sold-Marketing Expenses" (Kotler \& Armstrong, 2014). This study proposed NMC calculation in the previous paper (Hasan, 2012) for financial institutions as Net Marketing Contribution (NMC) $=$ Net Interest Income (Interest Income/Profit on Investment-Interest/Profit paid on deposits and Borrowings, etc.)-Marketing Expenditure (Advertisement \& Publicity) and the calculation of NMC for first generation commercial banks in Bangladesh is given in Table 1. The computation of NMC can be formally presented as follows:

$\mathrm{NMC}=$ Net Marketing Contribution

$$
N M C_{b t}=N I I_{b t}-M E_{b t} \ldots \ldots \ldots . . e q
$$

$\mathrm{b}=$ Different Bankst $=$ Time period

$\mathrm{NII}=$ Net Interest Income

$\mathrm{ME}=$ Marketing Expense

\subsubsection{Interest Income As Sales Revenue}

Revenues from a business's primary activities are reported as sales, sales revenue or net sales. This includes product returns and discounts for early payment of invoices. All companies need to sell to accurate benefits that help the company to grow and survive and banks are not an exception. If we search in any dictionary for a definition of sale, we can find something like: "the exchange of goods or services for an amount of money or its equivalent" (Dictionary.com, 2010). Most businesses also have revenue that is incidental to the business's primary activities, such as different charges earned from 
services. This is included in revenue but not included in net sales. Sales revenue does not include sales tax collected by the business.

A bank's interest revenue is placed in a comprehensive income statement in the Bank's annual report and is separate to investment revenue and other revenues. Defining other revenue (a.k.a. non-operating revenue) is as revenue from peripheral (non-core) operations. For example, a company that manufactures and sells automobiles would record the revenue from the sale of an automobile as "regular" revenue. If that same company also rented a portion of one of its buildings, it would record that revenue as "other revenue" and disclose it separately on its income statement to show that the revenue is from something other than its core operations.

Financial income from activities those are ordinary for a particular corporation, company, partnership, or sole-proprietorship. For some businesses, such as manufacturing and/or grocery, most revenue is from the sale of goods. Service businesses such as law firms and barber shops receive most of their revenues from rendering services. Lending businesses such as car rentals and banks receive most of their revenue from fees and interest generated by lending assets to other organizations or individuals.

\subsubsection{Advertising \& Publicity as Marketing Expense}

"Advertising and publicity" has been counted as marketing expenses for measuring the bank's marketing contribution. Roger J. Best (2010) opined that marketing expense should not include general administration expenses, R\&D expenses or other expenses unrelated to the marketing \& sales of company's products and services. Therefore, MROI can be higher even in less investment on marketing expense as "Advertising \& publicity". This statement has been proved in the paper of "ROI Analysis for bank branding, marketing and customer service" by the estimation of MROI which is 709\% (Hinshaw, 2006).

Every marketing activity has been under greater pressure for its contribution to firm value rather than its advertising. While advertisers focus heavily measures such as awareness, the finance manager might be concerned with what a point of awareness means in terms of financial consequences. Many studies that assess the value of advertising have shown a negative return (Lodish et al., 1995). This is not unusual, because the effects of advertising are typically long term (Dekimpe et. al., 2004). This temporal separation of the returns as illustrated by the case of advertising becomes a cause of concern when the returns do not get accounted with expectations.

\section{Table 1. NMC of Banks in Different Years (Taka in Million)}

\begin{tabular}{llllll}
\hline Banks & 2009 & 2010 & 2011 & 2012 & 2013 \\
\hline Arab Bangladesh Bank (AB)Ltd. (AB) & 2,856 & 3,429 & 2,352 & 3,083 & 3,748 \\
International Finance Investment \& Commerce Bank Ltd. (IFIC) & 1,080 & 2,055 & 1,978 & 2,757 & 2,574 \\
Uttara Bank Ltd. (UB) & 1,691 & 1,870 & 2,445 & 1,725 & 941 \\
Pubali Bank Ltd. (PBL) & 4,256 & 5,162 & 6,258 & 7,384 & 5,336 \\
\hline
\end{tabular}




\begin{tabular}{|c|c|c|c|c|c|}
\hline National Bank Limited (NBL) & 2,451 & 3,917 & 5,208 & 5,408 & 2,750 \\
\hline Islami Bank Bangladesh Ltd. (IBBL) & 8,263 & 10,234 & 13,541 & 17,685 & 16,990 \\
\hline The City Bank Ltd. (CITY) & 1,932 & 3,375 & 4,221 & 4,608 & 4,860 \\
\hline United Commercial Bank Ltd. (UCBL) & 2,567 & 3,764 & 5,058 & 6,530 & 7,014 \\
\hline
\end{tabular}

* Bold Indicates either Highest Value or Lowest Value.

\subsection{Marketing Return On Investment (MROI)}

Marketing ROI is another important tool of marketing profitability metrics. MROI contributes $70 \%$ to measure customer loyalty and $66 \%$ to measure the customer profitability/value (Hinshaw, 2006). Most marketing literature and practice have tended to rely on ROI (or, MROI, where the "M" stand for "Marketing") in a more generic sense as a means of outcome measurement. There are simple reasons to believe that the development and use of effective measures of return on marketing investment can produce greater returns for the firm while reducing total current marketing costs. The returns and cost savings obtained by firms that have successfully embraced the continuous quality improvement movement give us confidence that similar attention to the role of marketing in contributing to the financial performance of the firm will produce significant returns. While there are many marketing metrics that may be useful for diagnostic and tactical purposes, MROI is ultimately about economic outcomes, i.e., financial results. This is only a measures that can be linked to financial results will be credible because the firm is required to report its results in financial terms.

Most marketers will increasingly be required to justify their expenditure in terms of ROI. The acceptance of results will largely depend on the integrity of the data used to make them. It is simply the net marketing contribution divided by marketing and sales expenses. For an example, when Apple's 2009 NMC of $\$ 10$ billion is divided by their $\$ 3.12$ billion investment in marketing and sales (M \& SE), a Marketing ROI of 325 percent is produced. This means that Apple strategies collectively produced $\$ 3.25$ in net marketing contribution for every dollar invested in marketing and sales.

Often, Marketing ROI models show ridiculously high returns because they do not incorporate all relevant variable and semi-variable costs, such as staff costs for marketing departments, travel expenses, and the cost of sales' time. Seventy-six percent (76\%) of B2B marketing professionals agree or strongly agree that their "ability to track marketing ROI gives marketing more respect" (Dow, Forrester Research, 2013). According to a Lenskold Group/emedia Lead Generation Marketing ROI Study (2010), the number one metric used by lead generation marketers is lead quantity, whereas barely half of marketers measure lead quality.

MROI must be an inherently financial construct (Stewart, 2008). No measure or measurement system is complete without a specific link to financial performance. Stewart explains some important contributions in his paper that helps to create the perception of MROI necessity. MROI contributes to economic outcome and impact of marketing actions. Return, risk, the time value of money and the cost of capital are reflected by MROI. It has also the ability to recognize the short time effect of marketing Published by SCHOLINK INC. 
actions and long term outcomes. Few other important contributions of MROI are sound decision making, accountability, continuous improvement, and transparency for all stakeholders. Here, this study proposed the computation of "Marketing return on investment" (MROI) in the previous paper (Hasan, 2012) for financial institutions as $M R O I=$ Net marketing contribution/Marketing expenditure and the calculation of MROI for first generation commercial banks in Bangladesh is given in Table 2. The computation of MROI can be formally presented as follows:

MROI=Marketing Return on Investment

$\mathrm{b}=$ Different Banks

$$
M R O I_{b t}=\frac{N M C_{b t}}{M E_{b t}} \ldots \ldots \ldots \ldots \ldots . . . e q
$$

$\mathrm{t}=$ Time period

$\mathrm{NMC}=$ Net Marketing Contribution

$\mathrm{ME}=$ Marketing Expense

Table 2. MROI of Banks in Different Years

\begin{tabular}{llllll}
\hline Bank & 2009 & 2010 & 2011 & 2012 & 2013 \\
\hline AB & $5441.80 \%$ & $6593.76 \%$ & $5572.64 \%$ & $7708.78 \%$ & $11977.68 \%$ \\
IFIC & $4980.59 \%$ & $9751.78 \%$ & $6615.12 \%$ & $5698.93 \%$ & $5942.77 \%$ \\
UB & $15244.79 \%$ & $15352.48 \%$ & $21314.15 \%$ & $11417.16 \%$ & $5302.10 \%$ \\
PBL & $12022.72 \%$ & $10041.53 \%$ & $11235.31 \%$ & $11065.98 \%$ & $8372.01 \%$ \\
NBL & $3855.73 \%$ & $7502.39 \%$ & $13573.16 \%$ & $34952.79 \%$ & $14785.98 \%$ \\
IBBL & $27270.16 \%$ & $17056.69 \%$ & $17430.87 \%$ & $15086.40 \%$ & $9430.48 \%$ \\
CITY & $1385.33 \%$ & $1697.49 \%$ & $2139.74 \%$ & $2840.71 \%$ & $3048.08 \%$ \\
UCBL & $5098.95 \%$ & $5307.37 \%$ & $5576.08 \%$ & $7806.42 \%$ & $10632.35 \%$ \\
\hline
\end{tabular}

* Bold Indicates either Highest Value or Lowest Value.

\subsubsection{Discounted MROI Using Perpetual NPV Continuous Discount Factor}

In the quantification of value to pay for bank's brand, an investor of a business ultimately looks to the return of reputation from the brand he will receive on his investment. That returns might come in the form of II, MROI, NMC and ME influence to the quantification of brand value. The valuation approach of this paper demands continuously discounted future values that will be forecasted by linear regression using historic data (2009-2013). Forecasts are usually for five or seven years during the rapid growth phase with a convergence in the final years of the forecast to a long-term stable growth rate (Hawkins, 2001). Each of the future data (2014-2018) has been discounted back to its present worth at an appropriate discount rate.

In this study, risk free rate has been used as perpetual NPV continuous discount factor. Risk free interest rate is the theoretical rate of return of an investment with zero risk, including default risk (Investopedia, 2009), as this is the lowest threshold of return, an investor would expect, so risk free rate 
of interest can be used as perpetual discount factor. In several researches, risk free rate is used for discounting different purposes, such as Investopedia (2009) used it to analyze performances of mutual funds. Therefore, we would like to determine the risk free rate by the geometric mean of cut off yield percentage in the category of 91 days treasury bill. Data have been considered for this study from 2009 to 2013 . This study has considered the risk free rate by geometric mean which is $6.60 \%$.

In this proposed calculation of $\mathrm{BV}$, we need to formulate the CDMROI (Continuously Discounted MROI) for scoring relative brand strength. The calculation of CDMROI for first generation commercial banks in Bangladesh is given in Table 3. The CDMROI will be computed by CDNMC (Continuously Discounted Net Marketing Contribution) and DME (Continuously Discounted Marketing Expense). Here CDMROI, CDNMC and CDME can be formally presented as follows:

$$
\begin{aligned}
& C D M R O I_{b}=\frac{C D N M C_{b}}{C D M E_{b}} \ldots \ldots \ldots \ldots \ldots . . . e q \\
& C D N M C_{b}=\int_{0}^{t} N M C_{b}(t) e^{-t r} d t \ldots \ldots \ldots \ldots \ldots . . . e q \\
& C D M E_{b}=\int_{0}^{t} M E_{b}(t) e^{-t r} d t \ldots \ldots \ldots \ldots \ldots \ldots . . e q
\end{aligned}
$$

DMROI=Discounted Marketing Return on Investment

$\mathrm{b}=$ Different Banks

$\mathrm{t}=$ Time period

$\mathrm{NMC}=$ Net Marketing Contribution

$\mathrm{ME}=$ Marketing Expense

$\mathrm{r}=$ Risk free rate

Table 3. Continuously Discounted MROI of Banks (Considering Projected Year from 2014 to 2018)

\begin{tabular}{llll}
\hline Bank & Continuous Discounted NMC (TK in Million) & $\begin{array}{l}\text { Continuous Discounted ME } \\
\text { (TK in Million) }\end{array}$ & Continuous Discounted MROI \\
\hline AB & 9,106 & 142 & 64.12 \\
IFIC & 5,643 & 86 & 65.61 \\
UB & 5,563 & 38 & 146.39 \\
PBL & 16,393 & 152 & 107.84 \\
NBL & 11,572 & 138 & 83.85 \\
IBBL & 35,794 & 216 & 165.71 \\
CITY & 10,193 & 519 & 19.63 \\
\hline
\end{tabular}




$\begin{array}{llll}\text { UCBL } & 12,942 & 211 & 61.33\end{array}$

* Bold Indicates either Highest Value or Lowest Value.

\subsection{Brand Strength}

Brand strength is known, relative brand strength is determined by juxtaposing absolute brand strength for the brand in question against the absolute brand strength of competitor brands already analyzed (Huber et al., 2001). In this study, we would like to propose for measuring the "Brand Strength" by the individual bank's weight of Marketing Return on Investment. The calculation of Relative Brand Strength (RBS) for first generation commercial banks in Bangladesh is given in Table 4. The computation of RBS can be formally presented as follows:

RBS=Relative Brand Strength

$$
R B S_{b}=\frac{D M R O I_{b}}{\sum D_{R R O I}} \ldots \ldots \ldots \ldots \ldots \ldots \ldots . . e q
$$

$\mathrm{b}=$ Different Banks

$\mathrm{NMC}=$ Net Marketing Contribution

DMROI=Discounted Marketing Return on Investment

Table 4. Score of Relative Brand Strength (2009-2013)

\begin{tabular}{lll}
\hline Bank & Continuously Discounted MROI & Relative Brand Strength \\
\hline AB & 64.12 & 0.08974359 \\
IFIC & 65.61 & 0.091829023 \\
UB & 146.39 & 0.20489027 \\
PBL & 107.84 & 0.150934946 \\
NBL & 83.85 & 0.117358079 \\
IBBL & 165.71 & 0.231930915 \\
CITY & 19.63 & 0.027474527 \\
UCBL & 61.33 & 0.085838652 \\
\hline
\end{tabular}

* Bold Indicates either Highest Value or Lowest Value.

\section{Brand Valuation Analysis and Findings}

"Brand value" is the strategic and financial measure of a brand. "Brand valuation" is defined as a financial exercise which is intended to put a monetary value. The brand-specific discount rate is used to discount brand earnings back to a present value, reflecting the likelihood that the brand will be able to withstand challenges and deliver the expected valuation into the future. This is equal to brand value. According to the idea of ACNielsen (2006), the monetary value of brand is measured by estimated market volume is then multiplied by the annual net operating margin to calculate the earnings potential of the market as a whole. The brand value share of the brand for the current business year is determined by multiplying this sales potential and relative brand strength. Next, brand value is determined by assuming an annuity in perpetuity, discounting future brand earnings using a capital market interest 
factor. The formula of this valuation is given as $B V_{b}=$ "Annual sales of respective brands" $\mathrm{x}$ "Net operating margin" $\mathrm{x}$ "Relative brand strength" x "Perpetual annuity NPV discount factor".

Here we would like to propose the computation of BV for financial institutions as

$B V_{b}=$ "Annual Interest Income of respective commercial banks" $\mathrm{x}$ "NMC margin" $\mathrm{x}$ "Relative brand strength" $\mathrm{x}$ "Perpetual NPV continuous discount factor" is given in Table 5. The computation of BV can be formally presented as follows:

$$
\operatorname{BrandValuation}\left(B V_{b}\right)=\sum C D I I_{b} \times \frac{\sum C D N M C_{b}}{\sum C D I I_{b}} \times R B S_{b} \ldots \ldots \ldots \ldots . . . e q
$$

ContinuouslyDiscountedInterestIncome $\left(C D I I_{b}\right)=\sum_{0}^{b} \int_{0}^{t} I I_{b}(t) e^{-t r} d t \ldots e q$

$$
N M C P e r c e n t a g e\left(\frac{\sum C D N M C_{b}}{\sum C D I I_{b}}\right)=\frac{\sum_{0}^{b} \int_{0}^{t} N M C_{b}(t) e^{-t r} d t}{\sum_{0}^{b} \int_{0}^{t} I I_{b}(t) e^{-t r} d t} \ldots . e q
$$

$$
R B S_{b}\left(\frac{C\left(\mathrm{MROI}_{b}\right.}{\sum \mathrm{CDMROI}_{b}}\right)=\frac{\int_{0}^{t} N M C_{b}(t) e^{-t r} d t}{\sum_{0}^{b} \frac{\int_{0}^{t} M E_{b}(t) e^{-t r} d t}{\int_{0}^{t} M C_{b}(t) e^{-t r} d t}} \ldots \ldots . . e q
$$

$$
(t) e^{-t r} d t \times \frac{\sum_{b=1}^{8} \int_{t=5}^{10} N M C_{b}(t) e^{-t r} d t}{\sum_{b=1}^{8} \int_{t=6}^{10} I I_{b}(t) e^{-t r} d t} \times \frac{\int_{t=5}^{10} N M C_{b}(t) e^{-t r} d t}{\sum_{b=1}^{8} \frac{\int_{t=5}^{10} N E_{b} e^{-t r} d t}{\int_{t=5}^{10} M C_{b}(t) e^{-t r} d t} \ldots \ldots e q}
$$

$B V_{b}=$ Brand Value of a particular commercial bank

$\mathrm{b}=$ commercial banks (Where $\mathrm{b}=1 \ldots . .8$ )

$\mathrm{t}=$ Time period $($ where $\mathrm{t}=5 \ldots \ldots 10)$

$r=$ Risk free rate 
$\mathrm{CDII}_{\mathrm{b}}=$ Continuous discounted interest income of a particular bank

$\mathrm{CDNMC}_{\mathrm{b}}=$ Continuous Discounted net marketing contribution of a particular bank

$\mathrm{CDMROI}_{\mathrm{b}}=$ Continuous Discounted marketing return on investment

$\mathrm{RBS}_{\mathrm{b}}=$ Relative brand strength of a particular bank

Table 5. Brand Value Calculation for the Ended Year of 2013

\begin{tabular}{lllll}
\hline \multirow{2}{*}{ Banks } & $\begin{array}{l}\text { Continuous Discounted Interest Income } \\
\text { of All Banks (TK in Million) }\end{array}$ & $\begin{array}{l}\text { NMC } \\
\text { Percentage }\end{array}$ & $\begin{array}{l}\text { Relative } \\
\text { Strength }\end{array}$ & $\begin{array}{l}\text { Brand } \\
\text { in Million) }\end{array}$ \\
\hline AB & $2,92,872$ & 0.36605009 & 0.08974359 & 9,621 \\
IFIC & $2,92,872$ & 0.36605009 & 0.091829023 & 9,845 \\
UB & $2,92,872$ & 0.36605009 & 0.20489027 & 21,965 \\
PBL & $2,92,872$ & 0.36605009 & 0.150934946 & 16,181 \\
NBL & $2,92,872$ & 0.36605009 & 0.117358079 & 12,581 \\
IBBL & $2,92,872$ & 0.36605009 & 0.231930915 & 24,864 \\
CITY & $2,92,872$ & 0.36605009 & 0.027474527 & 2,945 \\
UCBL & $2,92,872$ & 0.36605009 & 0.085838652 & 9,202 \\
\hline
\end{tabular}

* Bold Indicates either Highest Value or Lowest Value.

In the calculation of BV, IBBL holds the first position and CITY bank is the lowest shown in Table 5. It is also shown in Table 3 that IBBL holds the first position and UB has the lowest position in CDNMC. On the other hand, CITY holds the first position and UB has the lowest position in DME. Considering the top three positions, BV shows IBBL, UB and PBL respectively, DNMC shows IBBL, PBL, and UCBL respectively, and DME shows CITY, IBBL and UCBL respectively.

\section{Recommendations}

The increasing recognition of brand as an important asset has lead to realization that the return from marketing should be seen as the incremental marketing contribution and marketing return on investment together with the change in the value of the brand. This factor seeks to bridge the gap between marketing and finance by justifying marketing investment and resource allocation in financial terms. The quantification of Brand Valuation has been valued by extracted data from annual report of first generation of commercial banks in Bangladesh. The computation of this valuation approach can create more accuracy of bank's marketing performance. Results and techniques of this computation can be a new opportunity to track the marketing related input and output for the banks. The technique of this brand valuation can be effective measure to control "Interest income", "Interest paid on deposits and borrowings" and "Advertising and publicity as Marketing expense" of commercial banks. This study also indicates that this valuation approach is influenced by the ratio of "Interest income" and "total operating income". Usually more interest income compare to investment income is more influential to increasing trend of brand value. This approach may have significant application for the 
decision making of strategic brand management. This paper recommends that the study of brand valuation should be more concerned along with Financial Profitability.

\section{Conclusions}

The intention is very clear to measure the marketing effectiveness and accountability. The results of this assessing brand value can be influential to restructuring portfolio management, protecting marketing budget, making decision about brand activity and assessing performance of marketing personnel of banks. Before introducing this valuation, we are almost in dark about the objective measure of BV of financial institution particularly commercial banks. Despite the many other financial tools of measuring performance and productivity, brand management of banks are in confusion about the usage of valuation tools from where they can expect actual return of brand related activities. Assessing overall marketing performance based on non financial measures (market share, quality, customer satisfaction, loyalty, and brand equity) may change even in within a second due to the volatility of customers' perception. Therefore, Banks should focus on measuring BV to track the performance by analyzing their financial data. Despite the value of brand is subject to the number of banks and period of time, decision makers could rely on this valuation for the justification of their investment. The calculated way of BV can be debated further in future study. But it is necessary to perform this valuation approach in the field of Bank Marketing into the financial sector for making decision more effectively. The contribution of this study will be successful if banks are interested to apply this Brand Valuation approach.

\section{References}

Aaker, D. (1991). Managing Brand Equity: Capitalizing on the value of a brand name. The Free Press, New York.

Aaker, D., \& Alvarez del Blanco, R. (1995). Estatura de la marca: Medir el valor por productos and mercados. Harvard Deusto Business Review, 69, 74-87.

Abratt, R., \& Bick, G. (2003). Valuing brands and brand Equity: Methods and processes. Journal of Applied Management and Entrepreneurship, 8(1), 21-39.

Nielsen, A. C. (2006). AC Nielsen Brand Performance. Germany, presentation prepared by M. G. Schilken from AC Nielsen, \& O. Franzen from Konzept \& Markt GmbH.

Andriessen, D. (2004). Making Sense of Intellectual Capital: Designing a Method for the Valuation of Intangibles. Elsevier, Oxford.

Ambler, T., \& Barwise, P. (1998). The trouble with brand valuation. Journal of Brand Management, 5(5), 367-376.

Anson, W. (2005). Fundamentals of Intellectual Property Valuation: A Primer for Identifying and Determining Value. American Bar Association, Chicago.

Barwise, P., Higson, C., Likierman, A., \& Marsh, P. (1989). Accounting for Brands. London Business 
School/The Institute of Chartered Accountants in England and Wales.

BBDO. (2004). Brand Valuation has established itself on top management agendas. Point of View 5, BBDO Consulting, March, Germany.

Beccacece, F., Borgonovo, E., \& Reggiani, F. (2006). Risk Analysis in Brand Valuation. July, Bocconi University, Milano, Italy.

Bekmeier, F. S. (1998), Marktorientierte Markenbewertung: Eine konsumenten-und unternehmensbezogene Betrachtung. Wiesbaden, Gabler, 1998.

Best, R. J. (2010). Market-Based Management (5th ed.). Prentice Hall, New Jersey, NJ.

Blackett, T. (November, 1989). The role of brand valuation in marketing strategy. Marketing and Research Today, 17, 245-248.

Boos, M. (2003). International Transfer Pricing: The Valuation of Intangible Assets. Kluwer Law International, The Hague.

Brand Economics. (2002). Bringing new clarity to brand management and strategy. New York.

Brand Finance. (2000). Current Practice in Brand Valuation. Gee Books, London, June.

Brandient. (September, 2004). Capital is a valuable brand, 40. Romania.

Brand Metrics. (2004). Outline of Model. Retrieved from http://www.brandmetrics.com/outline.htm

Calderón, H., Cervera, A., \& Mollá, A. (1997). Brand assessment: A key element of marketing strategy. Journal of Product \& Brand Management, 6(5), 293-304.

Callaman, S. (2002). Firm devises equation to quantify brand value. BtoB Magazine, 15 July. Retrieved from http://findarticles.com/p/articles/mi_go1547/is_200207/ai_n7166429

Corebrand. (2004). Directory of Brand Equity ${ }^{\mathrm{TM}}$ : Quarterly Report. Retrieved from http://www.corebrand.com

Crimmins, J. C. (1992). Better measurement and management of brand value. Journal of Advertising Research, 11-19.

Damodaran, A. (1996). Investment Valuation. John Wiley \& Sons, New York.

Dekimpe, M. G., Hanssens, D. M., Nijs, V. R., \& Steenkamp, J-B. E. M. (2003). Measuring short-and long-run promotional effectiveness on scanner data using persistence modeling. ERIM Report Research in Management, ERS-2003-087-MKT.

Dow, G. (2013). The key marketing metrics your CEO cares about. Forrester Research. Retrieved from http://www.newbreedmarketing.com/blog/marketing/the-key-marketing-metrics-your-ceo-cares-ab out

Drefeldt, K. C. (1994). Member of the Swedish body Bokföringsnämnden (Interview). Board member of IREV, Lecturer in Qualified Accounting Issues, 2006-05-21.

Farhana, N., \& Islam, S. (2012). Analyzing the brand equity and resonance of banking services: Bangladeshi consumer perspective. World Review of Business Research, 2(4), 148-163.

Fernandez, P. (December, 2001). Valuation of Brands and Intellectual Capital. Retrieved from http://SSRN: ssrn.com/abstract=270688 or DOI: $10.2139 /$ ssrn.270688 
Fischer, M. (2007). Valuing brands: A Cost-Effective and Easy-to-Implement Measurement Approach. Marketing Science Institute, Report \# 07-107, Cambridge, Mass.

Gunthar, T., \& Kling, K. C. (2001). Brand valuation and control: An empirical study. Schmalenbach Business Review, 53, 263-294.

Haigh, D. (2000). Brand Valuation: Measuring and Leveraging your Brand. A report prepared for the Institute of Canadian Advertising, May.

Hasan, M. (2012). Measuring marketing profitability metrics of first generation private commercial banks in Bangladesh. Journal of Marketing, 15, 267-286. Dhaka University.

Hawkins, G. B. (2001). Understanding the income valuation approach-A primer for judges who must hear valuation cases, Shannon Pratt, Editor-In-Chief. Judges \& Lawyers Business Valuation Update, A business valuation resources Publication, 3(3), 1-4.

Heider, U. H., \& Strehlau, R. (2000). Markenwert-Controlling. In Zerres, M. P. (Ed.), Handbuch Marketing-Controlling (pp. 497-520). Springer, Berlin and Heidelberg.

Herp, T. (1982). Der Markenwert von Marken des Gebrauchsgütersektors, Frankfurt am Main, Peter Lang.

Hinshaw, M. (2006). ROI Analysis for Bank Branding, Marketing and Customer Service. Western Independent Bankers Annual Marketing \& Business Development Conference, 1-43. Managing Partner, MCrop.

Hirose, Y. (June, 2002). The Report of the Committee on Brand Valuation. Ministry of Economy, Trade and Industry, the Government of Japan.

Intangible Business. (2001). Brand Valuation: Why and How. Retrieved from http:// www.intangiblebusiness.com

Huber, F., Herrmann, A., \& Morgan, R. E. (2001). Gaining competitive advantage through customer value oriented management. Journal of Consumer Marketing, 18(1), 41-53.

Interbrand Group. (2004). About the value of valuation. Amsterdam, The Netherlands: Interbrand Zintzmeyer \& Lux.

Investopedia. (2009). Risk free rate of return. Retrieved from http://financial-dictionary.thefreedictionary.com/Risk-Free+Rate+of+Return

Kam, S., \& Angberg, A. (2003). The Creation, Maintenance and Valuation of Brands. HVA. Retrieved from http://www.houlihanadvisors.com

Keller, K. L. (1998). Strategic brand management-Building, measuring, and managing brand equity. Upper Saddle River, NJ: Prentice Hall.

Kotler, P., \& Armstrong, G. (2014). Principles of Marketing: Marketing by the Numbers (15th ed.). Pearson Education, Upper Saddle River, NJ.

Kumar, S., \& Hansted, B. K. (2004). Mergers and acquisitions: Making brand equity a key factor in M\&A decision making. Strategy \& Leadership, 32(2), 20-27.

Lamb, R. (2002). The Role of Intellectual Property and Intangible Assets in Merger and Acquisitions in 
Intellectual Property Assets in Mergers and Acquisitions.

Lodish, L. M., Abraham, M., Kalmenson, S., Livelsberger, J., Lubetkin, B., Richardson, B., \& Stevens, M. E. (1995). How TV advertising works: A meta-analysis of 389 real world split cable TV advertising experiments. Journal of Marketing Research, 32(1), 125-139.

Millward Brown Optimor. (March, 2006). BRANDZTMTOP 100 Power Brands. Retrieved from http://www.ft.com/cms/ 4683957a- c0a7-11da-9419-0000779e2340.pdf

Mohiuddin, M., Najibullah, S., \& Shahid, A. I. (2006). An exploratory study on intellectual capital performance of the commercial banks in Bangladesh. The Cost and Management, 34(6), 40-54.

Motameni, R., \& Shahrokhi, M. (1998). Brand equity valuation: A global perspective. The Journal of Product and Brand Management, 7(4), 275-290.

Mussler, S., Hupp, O., \& Powaga, K. (2004). Evaluation of the Financial Value of Brands. GfK Custom Research Inc., Minneapolis.

Pratt, S. (2002). Cost of Capital: Estimation and Applications (2nd ed.). John Wiley \& Sons, New Jersey.

Ranatunga, J., \& Ewing, M. T. (2009). An ex-ante approach to brand capability valuation. Journal of Business Research, 63(3), 323-331.

Rank Hovis McDougall plc. (1989). Brands on the Balance Sheet. Rank, Hovis and McDougall, Windsor, January.

Reilly, R. F., \& Schweihs, R. P. (1999). Valuing Intangible Assets. McGraw-Hill, NY.

Rendon, W. M., \& Morales, K. R. (2013). Brand valuation: A review of Interbrand ${ }^{\mathrm{TM}}$ and Brand Capability Value ${ }^{\mathrm{TM}}$ Models. International Journal of Management Research and Business Strategy, 2(1), 121-129.

Revell, J. (1980). Costs and Margins in Banking: An International Survey. OECD, Paris.

Salinas, G. D., \& Ambler, T. (2009). A taxonomy of brand valuation practice: Methodologies and purposes. Journal of Brand Management, 17(1), 39-61.

Sattler, H., Högl, S., \& Hupp, O. (August, 2002). Evaluation of the Financial Value of Brands. Research Papers on Marketing and Retailing, 7. Hamburg University.

Seetharaman, A., Nadzir, Z. A. B. M., \& Gunalan, S. (2001). A conceptual study on brand valuation. Journal of Product \& Brand Management, 10(4), 243-256.

Simon, C., \& Sullivan, M., (1993). The measurement and determinants of brand equity: A financial approach. Marketing Science, 12, 28-52.

Smith, G., \& Parr, R. (2000). Valuation of Intellectual Property and Intangible Assets (3rd ed.). John Wiley \& Sons, New York.

Smith, G. (1997). Trademark Valuation. John Wiley \& Sons, New York.

Srivastava, R. K., McInish, T. H., Wood, R. A., \& Capraro, A. J. (1997). The Value of Corporate Reputation: Evidence from the Equity Markets. Corporate Reputation Review, 1, 62-68.

Stewart, D. W. (2008). How marketing contributes to the bottom line. Journal of Advertising Research, 
48(1), 94-105.

Tekan, M. E. G., Far, E. M., Hajipoormashajee, M., \& Heshi, A. T. (2012). The special value assessment of bank's brand name on basis of CBBE Model (Case Study: Bank Saderat). Advances in Environmental Biology, 6(7), 2069-2081.

Tollington, T. (1999). The brand accounting side-show. The Journal of Product and Brand Management, 8(3), 204-217.

Upton, W. (April, 2001). Business and Financial Reporting: Challenges from the New Economy. FASB, Special Report n 219-A.

Virvilaitè, R., \& Jucaityte, I. (2008). Brand valuation: Viewpoint of customer and company. Engineering Economics, 1(56), 111-119.

Ward, K., \& Ryals, L. (2001). Latest thinking on attaching a financial value to marketing strategy: Through brands to valuing relationships. Journal of Targeting, Measurement and Analysis for Marketing, 9(4), 327-340.

Webster, F. E. J. (1992). The changing role of marketing in the corporation. Journal of Marketing, $56(4), 1-17$.

Whitwell, S. (2003). Understanding Brand Equity and Valuation. Intangible Business, London. Retrieved from http://www.intangiblebusiness.com

Zahid, M. S. I. (2008). Marketing of bank services: A comparative study on some selected private commercial banks in Dhaka City. Journal of Business and Economics, 3(1), 59-72. Daffodil International University.

Zimmermann, R., Klein, B. U., Sander, B., \& Tharek, M. A. (2001). Brand Equity Review, Brand Equity Excellence, 1. BBDO Group Germany, Düsseldorf. 